Anorthite $\ldots \ldots \ldots \ldots \ldots$ CaAlAlSi $_{2} \mathrm{O}_{8}$.

In this series the valences of some of the individual elements vary, but their total and also the number of atoms in each compound are the same.

The galena group illustrates an isomorphous series in which the individual valences and the total number of atoms may both vary.

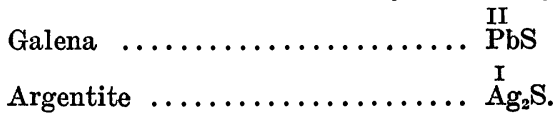

(For other examples of isomorphous series see Brauns's "Chemische Mineralogie," Arzruni's "Physikalische Chemie der Krystalle," and Groth's "Tabellarische Uebersicht der Mineralien," preferably the French edition of 1904.)

The similarity of beryl and benitoite is also to be noted by comparing their axial ratios. Both minerals crystallize in the hexagonal system.

Beryl $\ldots \ldots \ldots \ldots \ldots \ldots \ldots .{ }_{1}^{\alpha}: 0.4989$

Benitoite ............ $1: 0.4230$.

The value for benitoite is one half of one of those suggested by Louderback and is, no doubt, to be considered only as approximate, since no data concerning the reliability of the readings are given.

It is well known that $\mathrm{TiO}_{2}$ has either acidic or basic properties. In the case under consideration, the quantitative analysis simply reveals the presence of $\mathrm{TiO}_{2}$ as such. As to whether it is acid or basic, depends upon which of these assumptions will allow of the simplest explanation and yet be in strict accord with the observed facts.

The similarity of the composition of beryl and benitoite indicates a metasilicate and that $\mathrm{TiO}_{2}$ is to be considered basic in this instance. The metasilicates are very common in nature, which is not the case with the salts of $\mathrm{H}_{2} \mathrm{Si}_{4} \mathrm{O}_{9}$, a derivative of the tetrasilicic acid $\mathrm{H}_{4} \mathrm{Si}_{4} \mathrm{O}_{10}$, to which Louderback would refer benitoite. Up to the present time only one mineral, lorenzenite with the composition $\mathrm{Na}_{2}(\mathrm{Ti}, \mathrm{Zr})_{2}$ $\mathrm{Si}_{2} \mathrm{O}_{0}$, has been observed which can be referred to $\mathrm{H}_{2} \mathrm{Si}_{4} \mathrm{O}_{0}$. In lorenzenite, $\mathrm{Ti}$ and $\mathrm{Zr}$ replace two atoms of silicon, but in benitoite, according to Louderback's interpretation, one atom of silicon would be replaced by titanium. Thus, in both cases, $\mathrm{H}_{2} \mathrm{Si}_{4} \mathrm{O}_{0}$ is to be considered the basis. Hence, even though Louderback's interpretation be correct his statement, page 152, "Benitoite ... stands in a class by itself, both as regards acid silicates and titanosilicates," needs to be modified.

In a very recent paper by Ralph Arnold, it is pointed out that benitoite occurs in an area of basic rocks, such as serpentine and glaucophane schists. In fact, benitoite is found in cracks and cavities in the latter and is always associated with the hydrated basic metasilicate natrolite, $\mathrm{Na}_{2} \mathrm{Al}(\mathrm{AlO})$ $\left(\mathrm{SiO}_{3}\right)_{3} \cdot 2 \mathrm{H}_{2} \mathrm{O}$. According to Arnold, benitoite may have crystallized before the natrolite, but some-occurrences seem to indicate that probably the crystallization of these minerals was practically contemporaneous.

Therefore, the interpretation suggested above, which is based (1) upon the similarity of the chemical composition and axial ratios of beryl and benitoite; (2) upon the fact that $\mathrm{TiO}_{\mathrm{a}}$ may act as a base; (3) that benitoite occurs in an area of basic rocks, and (4) is always associated with the hydrated basic metasilicate, natrolite, seems amply justified. Accordingly, from what has been published, benitoite is not to be considered " a very acid titanosilicate of barium," but rather a metasilicate of barium and titanium.

Edward H. Kraus

\section{Mineralogical Laboratory,}

UNIVERSITY OF MTCHIGAN

\section{SOME PHYSICAL CHARACTERISTICS OF COLLEGE STUDENTS ${ }^{1}$}

A PHysical examination is required of all freshmen in Columbia College and the Schools of Applied Science during the first month of the academic year. The examination includes

2 " Notes on the Occurrence of the Recently Described Gem Mineral, Benitoite," by Ralph Arnold, Science, N. S., Vol. XXVII., pp. 312-314, 1908.

${ }^{1}$ Read before the New York Academy of Sciences, Section of Anthropology and Psychology, on October 28, 1907. 
a record of personal and family history, 31 measurements, 7 strength tests, vision and hearing tests, condition of skin, heart, lungs, nose, throat, teeth and of any abnormalities of spine, shoulders, chest, feet, etc.

The main purpose of these examinations is to help the medical director in guiding and advising each student in matters of physical exercise and hygienic living. The data collected are of interest to the physician and the anthropologist by showing the occurrence of various abnormalities and physical characteristics in healthy young men.

AVERAGE MEASUREMENTS OF 790 COLUMBIA STUDENTS 17,18 AND 19 YEARS OLD

\begin{tabular}{|c|c|c|c|c|c|}
\hline & \multirow{2}{*}{ 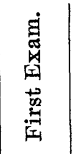 } & \multicolumn{3}{|c|}{ Averages } & \multirow{2}{*}{ 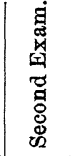 } \\
\hline & & 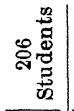 & 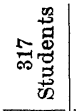 & 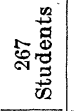 & \\
\hline \multicolumn{6}{|l|}{ 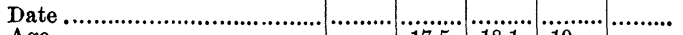 } \\
\hline & & 17.5 & 18.1 & 19 & \\
\hline & & 59.29 & 5986 & $6 \cap 22$ & \\
\hline lus & & lati & $\left|\begin{array}{lll}1 & i & 1 . j \\
1 & i & :\end{array}\right|$ & lis:ai & (....... \\
\hline Heig & & in. & 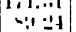 & $\begin{array}{l}1,1,1 \\
\vdots 1,1 \\
11\end{array}$ & \\
\hline$\cdots$ & & 63.67 & 63.9 & 64.63 & \\
\hline & & 33.5 & 33.79 & 34.27 & \\
\hline $\begin{array}{l}\text { Girth of Ulyer chest-Replose } \\
\text { Girth of I }\end{array}$ & & 84.44 & 85.08 & 86.17 & \\
\hline \multicolumn{5}{|l|}{$\begin{array}{l}\text { Girth of d pper chest-Aiter } \\
\text { Frpiration }\end{array}$} & \\
\hline \multicolumn{6}{|l|}{ 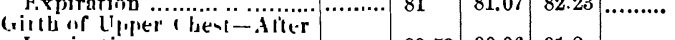 } \\
\hline \\
\hline & \multicolumn{5}{|c|}{ 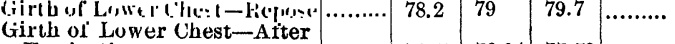 } \\
\hline \multirow{2}{*}{\multicolumn{6}{|c|}{ 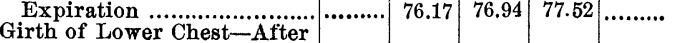 }} \\
\hline \multirow{2}{*}{\multicolumn{6}{|c|}{$\begin{array}{l}\text { Girth of Lower Chest-After } \\
\text { Inspiration }\end{array}$}} \\
\hline & & & 84.9 & 85.94 & \\
\hline \multirow{2}{*}{\multicolumn{6}{|c|}{$\begin{array}{l}\text { Girth of Right Upper Arm..... } \\
\text { Girth of Right Upper Arm- }\end{array}$}} \\
\hline & & & & & \\
\hline \multicolumn{6}{|l|}{ 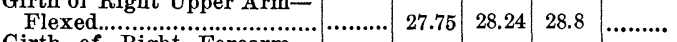 } \\
\hline \multirow{2}{*}{\multicolumn{6}{|c|}{ 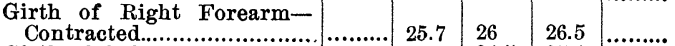 }} \\
\hline & & 25 . & & 26.5 & \\
\hline \multicolumn{6}{|l|}{ Girth of Left Upper Arm...... } \\
\hline 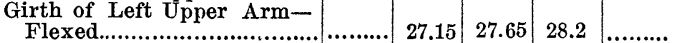 & & 27.15 & 27.65 & 28.2 & \\
\hline \multirow{2}{*}{\multicolumn{6}{|c|}{$\begin{array}{l}\text { Girth of Left Forearm-Con- } \\
\text { tracted }\end{array}$}} \\
\hline & & 24.97 & 25.32 & 25.67 & \\
\hline \multicolumn{2}{|l|}{ Girth of Right Thigh.............. } & 49.7 & & 50. & \\
\hline \multirow{2}{*}{\multicolumn{6}{|c|}{$\begin{array}{l}\text { Girth of Right Calf } . . . . . . . . . . . . . . \\
\text { Girth of Left Thigh.............. }\end{array}$}} \\
\hline \multirow{2}{*}{\multicolumn{3}{|c|}{ 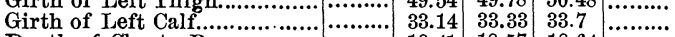 }} & & & \\
\hline & \multicolumn{5}{|c|}{ 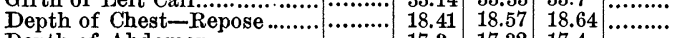 } \\
\hline \multicolumn{6}{|l|}{ Depth of Abdomen .................... } \\
\hline \\
\hline \multicolumn{6}{|l|}{ Breadth of Head.................. } \\
\hline & $\ldots$ & & & & ........ \\
\hline $\mathrm{Br}$ & ........ & & & & \\
\hline $\mathbf{B r}$ & & 24. & 24. & 25.15 & \\
\hline $\mathrm{Br}$ & & 21.88 & 31.98 & & \\
\hline & & "זיו" & 401.2 & & ........ \\
\hline of $|: !, 1,1 \quad|$ als al & & $\begin{array}{l}12.4 \\
411.95\end{array}$ & & \begin{tabular}{|l|}
50.84 \\
15
\end{tabular} & …..... \\
\hline $\mathrm{f} \mathrm{B}$ & & $\mid \begin{array}{l}40.8 \\
1: 1.75\end{array}$ & 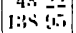 & & \\
\hline of J.es & & $\because 11 . x$ & 2.11 .1 & & \\
\hline Upper Arms & & & & & \\
\hline & & 4.39 & 5.43 & 5.9 & \\
\hline $\begin{array}{l}\text { Strength of Upper Arms } \\
\quad(\text { Pull Up) } \ldots \ldots \ldots \ldots \ldots \ldots \ldots \ldots\end{array}$ & & & 6.2 & & \\
\hline trength & & & & & \\
\hline
\end{tabular}

The occurrence of flat foot and weak foot appears to be increasing from year to year, as shown in the following table.

\section{ABNORMAIITIES OF THE FEET}

$\begin{array}{cc}\text { Class of } & \text { Class of } \\ \text { 1910, 364 } & 1911,305 \\ \text { Students } & \text { Students } \\ \text { Per Cent. } & \text { Per Cent. }\end{array}$

Normal feet ...... . . . . 6 61.2 48.2

Both feet flat ........... $15.4 \quad 16.9$

Both feet weak . . . . . . . . $20.4 \quad 29.5$

One foot weak ........... $1.8 \quad 3.6$

One foot weak and one flat ... $0.9 \quad 1.7$

The following table shows the occurrence of abnormalities of the spine. More than 95 per cent. of the abnormalities recorded in this table were postural and not pathological.

ABNORMALITIES OF THE SPINE $\begin{array}{cc}\text { Class of } & \text { Class of } \\ \text { 1910, 365 } & 1911,305 \\ \text { Students } & \text { Students } \\ \text { Per Cent. } & \text { Per Cent }\end{array}$

Normal spine ............ $18.3 \quad 15.4$

Kyphosis (round back) $\ldots \ldots \ldots 17.3 \quad 18.0$

Lordosis (hollow back) ...... $12.6 \quad 12.1$

Scoliosis (lateral curvature) $\ldots \quad 6.6 \quad 4.0$

All three abnormalities combined $15.6 \quad 13.7$

Kyphosis and lord sis ...... $20.5 \quad 29.0$

Kyphosis and scoliosis ....... $4.6 \quad 3.6$

Lordosis and scoliosis ....... $4.4 \quad 4.2$

Scoliosis alone or combined ... $31.2 \quad 25.5$

The nationality of the students is of interest in connection with the above data.

BIRTHPLACE OF 283 STUDENTS IN THE CLASS of 1911

United States . . . . . . . . $240 \quad 84.8$

Russia .............. 14

Canada $\ldots \ldots \ldots \ldots \ldots \ldots \ldots \ldots \ldots$

Austria ............. 4 4

Roumania ............. $3 \quad 1.0$

West Indies $\ldots \ldots \ldots \ldots \ldots \ldots \ldots .3 . \ldots \ldots$

Italy $\ldots \ldots \ldots \ldots \ldots \ldots \ldots \ldots .3 . \ldots$

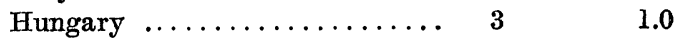

England ............. 2

Scotland $\ldots \ldots \ldots \ldots \ldots \ldots \ldots$ 1

India $\ldots \ldots \ldots \ldots \ldots \ldots \ldots \ldots$

China $\ldots \ldots \ldots \ldots \ldots \ldots \ldots \ldots$

Germany .............. 1

South America ........... 1

Japan .............. 1 
NATIONAIIT OF PARENTS OF 288 students

Per.

Cent

American (both parents) ....... 100

German (both parents) ....... 57

British (both parents) ........ 33

Hebrew (both parınts) ......... 20

Russian and Pole (both parents) . 16

Hungarian (both parents) ..... 4

Italian (both parents) ........ 3

Latin-American (both parents) ... 3

French (both parents) ......... 2

Scandinavian (both parents) .... 2

Chinese (both parents) ........ 1

Japanese (both parents) ........ 1

Roumanian (both parents) ...... 1

Bohemian (both parents) ....... 1

American and foreign ......... 12

Mixed foreign ............. 19

4.1

Three or more nationalities represent-

ed in parents and grandparents .. 13

G. L. MEYLAN

THE AMERICAN FEDERATION OF TEACHERS OF THE MATHEMATICAL AND THE NATURAL SCIENCES

GENERAL STATEMENT OF THE POLICY

THE officers of the federation deem it advisable to make the following brief statement of plans and policy, for the information of associations which may be interested in joining the organization.

The general purpose of the federation is to increase the efficiency of the federated (local) associations by bringing each of them into helpful cooperative relations with others that are working along similar lines in other parts of the country, and with the new Section $\mathrm{L}$ on Education of the American Association for the Advancement of Science.

The work of the federation through its officers and committees is expected in the near future to be developed along the following principal lines:

As a clearing house for the federated societies the federation will undertake to collect and to keep up-to-date information in regard to the work and the publications of these societies, and to aid as opportunity offers in the formation of new societies when needed.

As a publishing agency the federation will systematically print such of this information as may be of general interest in simple bulletins or in reports in scientific periodicals. Each federated society will be furnished with a list of the principal papers published in its field, and available to its members by purchase or exchange.

As a cooperative organization the federation will from time to time, of its own initiative or at the instance of a particular society, propose questions of general interest for the consideration of the federated societies, or appoint committees on questions of national scope in the teaching of science.

In relations with national societies, such as, for example, the American Association for the Advancement of Science, the National Educational Association, the National Society for the Promotion of Industrial Education, etc., the federation will endeavor to secure due recognition of the interests of the associations composing it, and of the great body of teachers of science.

At its Chicago meeting the American Association for the Advancement of Science showed its interest in and approval of the movement by affiliating the new federation with itself, and then extending to members of the federated associations the opportunity of joining the association without the usual initiation fee.

In general, the federation is expected in the future development of its policy to promote the advancement and improvement of science teaching in whatever manner may seem wise under the restrictions fundamental to its organization, which leave entire freedom of action to the federated associations, and which contemplate the transaction of federation business mainly 